УДК 821.163.41.09 Караџић В. С. 929 Караџић В. С. https://doi.org/10.18485/msc50.2019.1.ch2

\title{
Мирослав Пантић
}

\section{ВУК И ДУБРОВНИК}

Однос Вука Караџића и Дубровника био је, и остао, преважан у историји наше културе, а његови трагови видљиви су и данас. По природи својој, а исто тако и по опсегу, тај је однос многострук. За Вука, он се тицао Дубровника који је онда представљао прошлост, као и Дубровника који је Вуку био савремен. Он је обухватао не само историју знаменитога града, већ и његове обичаје и његов свакодневни живот, а пре, и надасве, његов језик. У том односу занимљиво је и значајно шта је од Дубровника Вук у себи носио, шта видео, а шта сазнао, како је све то доживео, и коликог је, и каквог, одраза затим то нашло у његовом делу и у одсудној борби коју је у нашој књижевности водио. Али, с друге стране, од подједнаког је интереса и шта је за Дубровник представљао Вук, како је он тамо схватан и у којој је мери био прихваћен.

У главним својим токовима однос који нас овде занима био је одавно истраживан и разматран ${ }^{1}$, и у претежном свом делу сада је и добро познат. Али има у њему и страна које су остале некако у сенци, као и

${ }^{1}$ Поред већих монографија, као што су: Љуб. Стојановић, Живот и рад Вука Стеф. Каращића, Београд, 1924, Миодраг Поповић, Вук Стеф. Караиић, Београд, 1964, Виктор Новак, Вук и Хрвати, Београд, 1967, у којима је било доста речи и о Вуковим путовањима у Дубровник и његовом односу према култури и језику тога града, и поред бројних лингвистичких расправа, у којима се, по природи ствари, разматра улога Дубровника у Вуковим погледима на српскохрватски језик, видети и посебно: Андра Гавриловић, Дубровачка полищија и В. С. Каращић, Полиција, X, 1923, 135-137; Алекса Ивић, Архивска грађа о српским книжевним и културним радницима 1740-1880, Београд, СКА, Зборник за ист., јез. и књиж. срп. народа, II одељ. књ. II, 1926, 281-288; Safet Barina, Vuk i Dubrovnik, Glasnik Jugoslovenskog profesorskog društva, XVIII, 1937, 433-439; Исти, Вук и Дубровник, Политика, 16. фебруар 1964; Г. Добрашиновић, Вукова путоваюа, Ковчежић, V, 1963, 75-119; В. М. Вукмировић, Вук у Дубровнику, Књижевност и језик, XII, $1965,4,44-59$. 
околности које су ретко и мало наглашаване. Покушали бисмо стога да га овде сагледамо у његовој свеукупности.

Вукова свест о Дубровнику и његова знања о прошлости и култури, као и о говору тог нашег јединственог града, нису, што је и сасвим природно, били једнаки у свих педесет година његовог рада у српском „Књижеству”. Они имају своје мене и своју линију развоја, једну своју историју у маломе, и у сагласности с њеним токовима Дубровник је добијао место и улогу у Вуковим размишљањима и решењима до којих је долазио, а већ стога неизбежно и у његовим списима. Сразмерно брзо, а затим све више, Дубровник је за Вука постајао чинилац од нарочитог значаја и као нека мера којом посматра, цени и одређује ствари и појаве у области језика, а унеколико и области литературе.

Из свога Тршића Караџић је могао да о Дубровнику понесе у сећању једва нешто више од понеког ретког помена у народним песмама или гдекоје појединости сачуване у веровањима и причама народа, попут оних о гласовитим дубровачким трговцима или о легендарним бравама дубровачким, на пример, које је као део свога детињства спомињао доцније, и баш у Дубровнику, и Милан Ђ. Милићевић. ${ }^{2}$ Несумњиво стога, у првим Вуковим књигама нема још увек ни трага од оне доцније тако уочљиве његове свести о посебности Дубровника у језику, а и у култури уопште.

Одређујући у Писменици (Беч, 1814), међе херцеговачког „наречија”, - које је за њега тада једно од три „предјелна нарјечија” на које се дели српски језик, а остала два су „сремско” и „славонско” - он је говорио да том наречју „принадлеже сви Сербљи који живе по Херцеговини, по Босни (како Греческога, тако и Мухамеданскога вјероисповједанија), по Церној Гори, по Далмацији, по Хрватској и по Сербији озго до Мачве, до Ваљева и до Карановца", али Дубровник није ту издвојено споменуо. У обема његовим Пјеснарицама, из 1814. и 1815, исто тако, нигде нема речи о Дубровнику, ни у оба „предсловија”, ни у самим песмама, чак ни у попису „пренумераната”. И када је ту говорио о опсегу и распрострањености српскога језика, и када је набрајао крајеве у којима би се могло сабрати много народних песама, и, најпосле, када је чинио напомене о језику самих песама, Вук је спомињао само уопштено „Далмацију” или

${ }^{2}$ М. Ђ. Милићевић, Из Београда на Цетиюе, Путне белешке, Видело, I, 1880, бр. 11 и 1. 
„Србље херцеговачког дијалекта (од Адријатическога мора, до Осјека, Лознице, Ваљева и до Карановца)”.

Али, радећи затим и ширећи просторе својих знања, што на подстицање пријатеља, Копитара, Мушицког и других, што од своје руке и вођен властитом радозналошћу, Вук је рано почео долазити у дотицај с књигама дубровачких аутора, а преко њих и с културом чији су израз они били. Већ од првих својих читања Рајићеве Историје, а потом и када je, у Карловцима 1815, разгледао рукописе Бранковићевих Хроника, он се сусрео и с именом дубровачког историчара Орбина - „Мавроурбина”, како су га они звали, и он му је постао један од извора у сазнавању националне историје. Орбиново дело, истина, Вук је морао знати не по оригиналу, већ по књизи штампаној 1722. у Русији под чудним називом Кюига историографија, где је оно било у избору и у преводу на руски нашег Саве Владиславића „грофа Рагузинског”. Ту књигу су у својим библиотекама имали онда поједини учени Срби, а међу њима Сава Текелија на пример. У Шишатовцу пак, где је Вук боравио децембра 1815. и у првим месецима наредне године, Л. Мушицки показивао му је књигу „попијевки”, „неке пјесме преведене на латински (и штампане)” са дубровачким записима песама старијих но што су били његови записи. Била је то, сасвим извесно, књига Ad clarissimum virum Joannem Muller Дубровчанина Ђура Ферића, тада живог још увек, штампана у Дубровнику 1798, чијих је тридесет седам песама, претежно народних, ако и не у њиховој латинској верзији, Вук могао читати барем у њиховим изворним почецима на „илирском” језику. А чим је почео да ради на Српском рјечнику, далековиди Копитар побринуо се да му прибави све раније штампане речнике, међу којима је наравно био и волуминозни речник Дубровчанина Јоакима Стулића, ${ }^{3}$ Зна се, из Објављьенија 1816. године ${ }^{4}$, да је Вук у то време био решен да у свој речник уврсти „све сербске ријечи” из тих ранијих речника, и из Стулићевог Рјечосложја према томе ${ }^{5}$, а да томе дода „јошт једну трећину правих србских ријечи, које се ни у једноме от речених рјечника не налазе”. У вези са развојем његових погледа у то време, у којима је Дубровник први пут, и готово би се рекло: одједном, добијао

3 Из манастира Шишатовца, у коме тада борави, крај Мушицког, Вук 14. јануара 1816, пише Копитару: „само вас јошт ово морамо (ја и г. Муш.) молити: да нам пошљете ваше све шокачке рјечнике, н. п. Штулија, Јамбрешића, Делабелу и Белостенца", Вукова преписка, I, 153.

4 Обявленіе о сербскомъ ръчнику (словарь, лексиконъ, Wörterbuch), Новине Сербске, 1816, бр. 88, 112, 172 (додаци).

5 „Све сербске ријечи које се налазе у рјечницима Курцбековом (који је само именом сербски), Делабели, Белостенцу, Јамбрешићу, Стулију, Волтиџију, Хајму...” 
издвојено место, занимљиво је да је Вук, у предлогу Милошу Обреновићу, негде крајем 1816, да њему посвети свој речник, уверавао српскога кнеза да ће свет на тај начин видети да се он, поред јуначких својих дела, брине „и за просвјештеније народа српскога”, уз веома карактеристичан додатак да ће му због тога бити благодарни" сви словенски народи од Петрова града до Дубровника".

Намеру да у Српски рјечник унесе пробрану лексику из дотле штампаних речника Вук ипак није остварио, на сву срећу могло би се рећи, мада је у том смислу бивао подржаван и подстицан не са једне стране. Мушицки га је подсећао, још и почетком 1817, да треба да у ту сврху чита Микаљу, као што је „публично” обећао 7 . А блиски његов пријатељ Лука Милованов, чак годину дана доцније, хвалио му је „њекакову грдну лексиконетину", писану далматински, италијански и, чинило му се, латински, коју је видео још 1809, и пожелео да прибави, јер је у њој морало „бити много којешта на нашем језику”. „Ако будеш га у руку имао, могао би ти сила помоћи”, напомињао је он Вуку. „Лексиконетина”, које се Милованов није више добро сећао био је у ствари речник Дубровчанина Стулића, који је Вук већ знао, али оно што није знао јамачно сазнао је истом приликом од Милованова, који је у рукама имао „Екстракт протокола придворне комисије која је о Штулином лексикону 1786. држана”. „Францишкан Штулиа - писао је Милованов -, и не увиђајући изгледа везу тог свог обавештења с непосредно пред тим поменутом „лексиконетином" - радио је о својем Лексикону 30 година. Шта ћеш ти, побро, на то рећи? Била је предлога учињена Двору да се овај Штулин речник као свеобшти лексикон за све језике или дијалекте илирическе: Далматинце, Крањце, Чехе, Тотове, Србље итд. трошком Царства печатати даде...”

Ту је управо била и линија која је раздвојила лексикографску мисао Вукову од мисли претходних аутора речника, и која га је коначно уверила да му ваља да иде својим путем, и не ослањајући се на њих у погледу лексичке грађе. „Словар овај - писао је он Стратимировићу марта 1818 - истина неће бити совршен, али ће бити бољи од свију шокачки' словара".' Тек неколико година доцније, у писму Гриму (21. дец. 1823) Вук ће до

${ }^{6}$ Вукова преписка, II, 535.

7 „Јесте ли прочитали Микаљу? Јесте ли се чим из њега ползовали?... Знате шта сте публично обећали", пише Мушицки из Шишатовца 6. фебр. 1817 (Вукова преписка, II, 139). „Ово ћу дана почети читати Микаљу, потом трејазични и академически словар (то ми је све Копитар набавио)", одговара Вук из Беча, 6 . марта 1817 (Исто, 144).

8 вукова преписка, II, 102.

9 Вукова преписка, III, 72. 
краја јасно изрећи зашто сматра „шокачке” лексикографе непоузданим ослонцима у језичким питањима: „Они верују да је њихово наречје прво и најстарије од свих словенских наречја, и они зато пишу речнике за све Словене, тако нпр. Стули има стотине (можда и хиљаде) руских речи. ${ }^{10}$

У предговору Српскога рјечника има једна шаљива Вукова опаска на рачун познатога историчара Енгела, а у вези с говором Дубровника, коју је он, не без сласти, понављао и доцније (напр. у Писму Димитрију Фрушићу, 1819). Не знајући „историје нашег језика и писања”, Енгел је на основу саме лектире Рајићеве Историје закључио „да се у Карловцима врло добро славенски мора говорити, зашто је Рајић онђе рођен, а онако добро пише славенски, и да је сремачки језик ближи к росијанскоме, него к дубровачкоме”.

Вуков Српски рјечник прва је његова књига за коју су се нашли претплатници („пренумеранти”) из Дубровника. Била је то овећа група, све самих трговаца из православног света, родом из Требиња, из Мостара, из Сарајева, из Стоца или из Бара („Из Дубовника 23 пренумеранта, и то све Бошњаци и Херцеговци”, како Вук јавља Мушицком, 30. септ. $1816)^{11}$, чије су се породице, или они сами, досељавали у Дубровник још од времена Републике и који су тад чинили далеко најпретежнији део дубровачке чаршије. На Вуков речник, а после и на све остале његове, а и на друге српске књиге, претплаћивали су се они, кад у већем, кад у мањем броју, обично и задуго исти, гдекад и не најлакше руке, и уз отпоре, али попуштајући пред наговорима ревносних сакупљача, па „баш ако ји' и не читају”, како је говорио у једној прилици сам Вук, а оно „само да би књижество свога рода потпомогли и списатељима издавање књига облакшали". 12 Међу пренумерантима на Српски рјечник није било ниједног „Шокца” или „Латина Дубровчанина”, како је Вук називао дубровачке католике, и неће их бити ни у низу његових књига из доцнијих година; поред опште апатије и небриге за књигу уопште у већем делу ондашњег дубровачког друштва, разлог ће за то бити још и што многи од тих Дубровчана нису ни читали ћирилицу, овако реформисану још поготово, а понеки су чак, под утицајем својих исповедника, страховали и од јереси које је у њима могло да буде.

Прилике у Дубровнику и његовој култури у оне деценије Вук је могао да прати такорећи стално, понајвише захваљујући личним везама с појединим Дубровчанима и својим кореспондентима из тог града, које је

\footnotetext{
10 Вукова преписка, II, 28.

11 Вукова преписка, II, 105.

12 Народне српске пјесме, књ. IV, у Бечу, 1833, Предговор, стр. XLIII.
} 
имао непрекидно, а понекад и више у исти мах. Први је, и најважнији, у њиховом низу свакако Јеремија Гагић, Шумадинац из Претока код Крагујевца, кога је Вук познавао још из устаничких дана као писара и другог секретара Правитељствујушчег совјета, а и из других тренутака његове променљиве судбине у Србији, с којим су он и Копитар провели у веселом и срдачном друговању знатан део 1816 . године ${ }^{13}$, и који је сада, као руски вице-конзул, а доцније и као конзул, био у Дубровнику велики господин и личност од значаја и утицаја. Гагић је Вука уистину волео и ценио, и осим у правопису делио је његове погледе у свему другоме. Ерудита и помало и сам човек од књиге, Гагић је био у преписци и пријатељству и с другим знаменитим људима свога времена, с Његошем или са Шафариком, на пример. Безмало на препад, он је освојио Дубровник и у њему нашао много пријатеља, чак и међу старом господом и међу песницима, који су му упућивали пригодне саставе у стиховима на разним језицима. ${ }^{14}$ Он се није само претплаћивао на Вукове књиге, него се и старао да се на њих претплаћују други из Дубровника; Вуку је он слао обавештења из града о људима и збивањима, а слао му је отуда и књиге; тамо га је он потом дочекивао и примао у свој дом. ${ }^{15}$

Међу Вуковим дубровачким знанцима у првом периоду његове делатности нарочито место припада Франческу Марији Апендинију, италијанском пијаристи који је као редовник и професор живео у Дубровнику још од последњих деценија Републике. Човек свестраних знања и писац велике плодности, какви су особито у XVIII веку били у моди, он је етимолог, граматичар, историчар, песник и биограф песника, историчар књижевности и културе, издавач разноврсних књига, својих и туђих. Када је 1823. боравио у Бечу, нешто због свога посла, а нешто и због послова школе којом је управљао, бивао је често, као стари пријатељ, с Копитаром, али Вук га није могао срести, јер се тада већ дуго налазио у „Германији”. И не знајући се лично годинама, Вук и Апендини одржавали су своју везу писмено, обично преко Ј. Копитара, још више преко J. Гагића, али исто тако и непосредно, све док се напокон нису срели у Дубровнику. Највећа је штета свакако што Вук није могао видети једну

13 О томе има пуно вести у писмима Вуковим Мушицком, али и у онима које је Вук добијао од Мушицког (вид. Вукова преписка, II, стр. 105, 107, 111, 113, 118, $121,135,137,138,144)$.

14 П. Колендић, Будимско издағе Гундулићева Османа, Cрђ, IV, 1905, 474. у нап.; P. Kolendić, Dubrovački pjesnici i Jeremija Gagić, Cpђ, IV, 1905, 11-12, стр. 513.

${ }^{15}$ Гагић и Вук су се дописивали деценијама (1817-1848); очувано је 41 Гагићево писмо Вуку, с предрагоценим обавештењима и подацима, и сва су штампана у трећој књизи Вукове преписке. 
збирку од педесет „шокачких попијевки” - „schokzische попъвке, назвао их је Копитар у свом бизарном макаронском стилу - које је крајем 1822 . Апендини хтео да штампа (што није учинио) и које је показао Копитару. За њих је учени Италијан тврдио да су прикупљене у Херцеговини и да их је у латинске хексаметре превео „један Дубровчанин”. ${ }^{16}$ Обавештен са стране Копитара о њима, Вук је помислио да ће то бити оне „попијевке” које је већ видео штампане у Шишатовцу $1815^{17}$, али то нису биле те „попијевке”, већ, несумњиво, збирка Slavica poemata latine reddita, коју је опремио и на латински превео такође Ђуро Ферић из записа песника Марка Бруеревића начињених у Травнику, а ваљда и по осталој Босни, на самом крају XVIII века ${ }^{18}$. Ко зна како би Вук судио о њој, да ју је видео, и не би ли она изменила, а можда и увећала, његову збирку, а у понечему одредила, а можда и проширила, нека његова гледања на усмено песништво.

Апендинија и Вука Караџића њихова литерарна и филолошка занимања, као и њихове књиге, морала су само тесно упућивати узајамно, па опет њихово духовно приближавање напредовало је споро и уз много препрека. Обојица су штампала граматике нашега језика, Апендини „илирског” и писану италијански, Вук језика српскога и штампану ћирилицом, а сваки од њих једва да је икада ближе проучио дело онога другог. Вук је тек много година доцније, и изгледа на упозорење свог тадашњег кореспондента из Дубровника Ђорђа Николајевића ${ }^{19}$, запазио пословице штампане уз Апендинијеву граматику, и пошто је из њих пробрао једну прегршт, разместио их је на одговарајућим страницама књиге, пропустивши потпуно да назначи свој извор ${ }^{20}$. Значајно Апендинијево дело Notizie istorico-critiche sulle antichità, storia e letteratura de' Ragusei (18021803), он је знао одраније, а убрзо га је и добавио за себе и за Шафарика, али једва да би се смело закључити да је с том књигом икад отишао даље

16 Вукова преписка, I, 210.

17 Исто, 211: „Ја сам још у Шишатовцу виђео неке пјесме преведене на латински (и штампане); ваља да ће то бити Апендинијеве попијевке. Врло ће ми драго бити ако изиђу на свијет, барем да и' видимо...”

18 О тој збирци вид. Мирослав Пантић, Народне песме у записима XV-XVIII века, Београд, 1964, стр. 218. и 275.

19 Вукова преписка, VII, 462: „Има доста лијепијех пословица у Апендинијевој Граматики, које ако немате, а ви ми јавите, да вам ји’ препишем...” (у писму из Дубровника 17/29. октобра 1836).

20 О томе вид. Мирослав Пантић, Вук Стефановић Караџић и наше народне пословище. (У књизи:) Српске народне пословице, Сабрана дела Вука Караџића, књ. IX, Београд, 1965, стр. 630-631. 
од пукога прелиставања ${ }^{21}$. Јер како би се иначе дала објаснити околност да се никада није осврнуо на Апендинијево расправљање о језику, као ни на његов текст о народним песмама, и да ниједном није узео у обзир „попијевку” О порази сватова дуждева Стјепана објављену у истом одељку те књиге? ${ }^{22}$ Непознавање о коме је реч још више упада у очи када су у питању остале њихове књиге. Вуку су до Апендинијевих списа пут затварали јамачно њихов италијански и латински језик; за Апендинија пак тешкоћу су у Вуковим књигама представљали подједнако и њихов језик и њихово писмо. Јеремија Гагић је с нарочитом ревношћу, и са поприлично пакости рекло би се, извештавао Вука о тим Апендинијевим отпорима: „Г. Апендини има врућичину у славенској етимологији (готовнословију) и при свем том све наопако толкује. Писмена наша не може желудац да му кува; он би рад да наше књиге чита, но никако да не учи наша писмена: говоре да је грјешно влашка слова учити (све људе восточног вјероисповједанија Власима називају)", писао је он тако 19. маја $1818 ;{ }^{23}$ „Господина Апендинија, љубитеља нашкога језика, имао сам прилику учтиво обличити у његовом предрасудку; он ни аза нашега не познаје, нити му смије загледати у очи, као јеретику, по запрештенију Пропаганде римскога вјероисповједанија, а хоће да зна что јеретички писатељи говоре”, додавао је две године доцније, 21. марта ${ }^{24}$. Због њих се Апендини и устезао да се претплати и на Српски рјечник, иако је раније то био обећао; када је књига најзад била пред изласком и када га је Гагић на то подсећао, изговарао се пословима и заузетошћу око припрема за дочек цара у Дубровнику, и на крају се ипак није претплатио; Рјечник је добио додуше, али од Копитара, не од Вука. ${ }^{25}$ Само о Вукове збирке народних песама Апендини није хтео да се тако оглуши, мада, ако се сме до краја веровати Гагићу, и у том случају није ствар прошла без подстицања са стране самога Гагића. Спремајући се да пише о Гундулићу и о

${ }^{21}$ Сасвим је сигурно да је према илустрацијама из те књиге, на којима су представљене дубровачке карневалске маске Бембеља, Турице и Чороја, Вук радио њихове описе у другом издању свог Српског рјечника (под речима Бембель и Чороје).

22 Препис те песме нашао се, додуше, касније у рукописима који су припадали Вуку и који су потом доспели у „петроградску царску библиотеку”. На препису те песме неко је забележио: „Из Notizie istorico-critiche од Appendini из II Тома стр. 259.” Одатле ју је Љуб. Стојановић уврстио у седму књигу Српских народних пјесама (Београд, 1900), под бр. 26.

${ }_{23}$ Вукова преписка, III, 6-7.

${ }^{24}$ Исто, 8.

${ }_{25}$ Исто, 6. 
његовоме Осману, Апендини се, по Гагићу, питао „може ли се што добро рећи о Вуковим србским пјеснама”, јер је мислио „да ништа љепше није од Качићеви пјесана о којима написао је био чрезвичајни панегирикон." ${ }^{26}$ Тек кад му је овај верни Вуков пријатељ нешто „шушнуо”, посао се „окренуо", и Апендини је изменио своје становиште. Али ако је из својих италијански писаних Успомена о животу и списима Ивана Франа Гундулића и изоставио припремљени „панегирикон” Качићу, није га зато доделио ни Вуку, него је говорећи о „илирским” народним песмама (le cosi dette Popjevke o canti nazionali Illirici) додао прилично неутралну напомену „под линијом”: „Види попијевке из Далмације које је скупио о. КачићМиошић, и оне из Босне и Србије које је објавио учени Вук Стефановић у Лајпцигу 1825 у три књиге”."27

Један дубровачки писац, и веома учени доминиканац, Анђео Маслаћ („по имену и дјелу Ангел”, како је с нежношћу Вуку о њему писао Гагић $)^{28}$ није имао страха од језика Вукових књига и од њиховога писма. Тај и иначе слободоумни фратар, од раније познат као ватрени присталица Француза, научио је, захваљујући Гагићевом „наставленију”, већ око 1820. године писмена старе и грађанске ћирилице, и дао се „с великом охотом” на читање Вукових Пјеснарица. „Не може ли се имати прва и друга част ваши' пјесана поради овога доброга филозофа”, - молио је Гагић у име овог ваљда првог, а у сваком случају веома раног читаоца народних српских песама међу „Латинима Дубровчанима”.29

Вукова знања о говору Дубровника и његово познавање дубровачке књижевности били су уистину скромни, и остали су тек у нејасним општим оквирима, током свих првих деценија његовога рада и заправо све до његовог непосредног сусрета са њима. Из његовог Додатка $\kappa$ Санктпетербургским сравнителним рјечницима свију језика и нарјечија (1822) види се тако да он из рђавих и непрецизних, па често и сасвим погрешних, бележења Тодора Јанковића „де Миријево” појединих „илирских” речи никако није могао препознати у ствари нимало ретке примере дубровачке лексике, па и старе дубровачке поезије, као што су, примера ради, суначие, пржина, повјетарие, дибина, стабар, хрек, хвоја или ћутјети. А све те речи, или безмало све, он је чуо и забележио понајвише управо у Дубровнику и унео их је, чак и с назнаком о месту беле-

${ }^{26}$ Иcmo, 16-17.

27 Francesco Maria Appendini, Memorie sulla vita e sugli scritti di Giovanni Frco Gondola, patrizio raguseo, autore del poema illirico intitolato l'Osmanide, Ragusa, 1827, 8.

28 Вукова преписка, III, 8.

29 Исто. 
жења, у друго издање свог Рјечника. Од давнашњих издања дубровачких писаца тешко да му је које доспело у руке, а ако баш и јесте, то је било само изузетно и сасвим ретко, и уосталом остало је без трага у његовим текстовима. Редак изузетак у том погледу представља песник Ђуро Ферић, из чије је књиге басана на теме из народних пословица (Fabulae ab illyricis adagiis desumptae, Дубровник, 1794) Вук преузео неке пословице и уврстио их у своју збирку те врсте усменог народног стваралаштва. ${ }^{30}$ Исти такав Вуков однос понавља се до краја и када су у питању издања старих Дубровчана која су света угледала код месног издавача Мартекинија почетком XIX столећа. Из Вукове преписке с пријатељима и знанцима међутим уочљиво је постепено ширење његових искустава у области књижевности старога Дубровника. Гагић му шаље оглас (објављење) за Јакшићев превод Османа на италијански језик, доцније и само то издање ${ }^{31}$, затим збирке пригодне поезије коју су њему у част последњи представници дубровачког стихотворства смислили и издали за венчани дан ${ }^{32}$ или пак оне, ништа боље и друкчије, којим су славили аустријског цара ${ }^{33}$. С пријатељем Игњатом Брлићем Вук измењује књижевна обавештења у којима је реч и о песницима старога Дубровника. На Брлићев упит он му јавља о скором двоструком штампању Гундулићеве Османиде, прво у Дубровнику и латиницом, и друго, старањем Јевте Поповића, у Будиму и ћирилицом. ${ }^{34}$ Када је међутим овај последњи своја ћирилска издања Гундулићевог Османа и Суза Радмилових Влађа Менчетића дао на свет под нечувено неспретним општим насловом Разна

30 М. Пантић, Вук Стебановић Карачић и наше народне пословище, 582, 631-632.

31 Вукова преписка, III, 14 (27. јуна 1826), 18 (16. јуна 1827: „Ево шиље вама г. Апендини по једну књигу (једну вама, а другу г. Копитару) простога превода Османа на италијански језик, с његовим описанијем живота Гондолина"). Реч је о књизи Versione libera dell' Osmanide, poema illirico di Giovanni Fr-co Gondola, patrizio di Ragusa, colla di lui vita dal Padre Francesco Maria Appendini delle scoule Pie, Ragusa, 1827.

32 Per le faustissime nozze del Sig. Cavaliere Geremia Gaguitsch, Consilgliere onorario di S. M. J. R. di tutte de Rusise colla Signora Eustachia Lucich, Ragusa, 1826.

33 Pel giorno natalizio di Sua Maestà Francesco I di Austria Imperatore e Re Versi, Ragusa, 1826.

34 У писму Игњату Ал. Брлићу из Беча 12/24. јануара 1826. Вук је знао, по чувењу, да ће Османиду „тријестински учитељ Јефта Поповић (родом из Сријемски' Карловаца) нашима словима да даде штампати” (Вукова преписка, V, 106), али 15/27. октобра исте године јавља о оба издања: „Писао сам вам из Будима да се у Дубровнику штампа Гундулићев Осман, којега прва књига (биће свега $m p$ и књиге), чујем да је већ изишла; у Будиму се пак штампа исти Осман и с нашијем словима (издаје га тријестански учитељ Јефта Поповић)...” (Исто, 199). 
дјела Јевте Поповића, Вуку је стигао Гагићев јаук из Дубровника у писму од марта 1828: „... Како је могао Јевто Поповић учинити ону absurditas и назвати Рагузински' учени' људи дјела својим дјелом? Зар Срби хоће у сваком случају да се показују с најружније стране? - Боље је ништа не чинити, него зло чинити. Матица дакле Србска није, по моему мњенију, Матица добра, него propaganda insaniae." ${ }_{55}$ Од Игњата Брлића, опет, Вук дознаје да је овај тада забављен прерађивањем „на наш прости говор” Палмотићеве Кристијаде, коју ће убрзо о свом трошку и издати ${ }^{36}$, а да Адам Филиповић преводи „на чистији језик” Мандалијену покорницу Дубровчанина „Игнација Ђорђи”. ${ }^{37}$ Понегде, на теренима Србије Вук ће се срести с траговима негдашње присутности старих Дубровчана, од којих ће неки за њега бити загонетка о којој ће дуго и у више наврата размишљати. Тако је већ 1818. године у свом Одговору господину - Ц - на юегово мненије о србској граматици застао пред поменом „Евангелија које је у Београду године 1552. печатано", ${ }^{38}$ питајући с очигледном неверицом и себе и свог опонента: „шта мисли г. -Ц- (то ће бити Павле, доцнији Платон, Атанацковић) да ли је то Евангелије печатано у србском Београду (на утоку Саве у Дунаво) или је у какоме другом?” Доцније је управо то Јеванђеље и сам Вук нашао у манастиру Благовештеније „на лијевом бријегу Мораве, под Кабларом” и укратко га описао у раду Почетак описанија српски намастира у „Даници” за 1826. годину, али није улазио у тајну коју је за њега представљало обавештење на књизи да ју је својим трошком штампао Радиша Дмитровић, а по смрти кнеза Радише довршио Тројан Гундулић „от великаго града Дубровника”. Када је пак 1857. у Примјерима српско-славенскога језика саопштио читав завршни текст из тог Јеванђеља, вратио се на питање места његовога штампања и на оно његовога издавача. Од три могућа Београда („данашњи српски”, или

35 Вукова преписка, III, 25.

36 Вукова преписка, V, 141 (писмо Брлићево из Сл. Брода 22. новембра 1830); Брлић још наводи да је Кристијада превод са латинског дела М. К. Виде, и даје опис издања тог дела, а као свој суд о њему каже: „Доста је прилично, али није ни слуга Клопфштоку",

37 У истом писму Брлић још наводи да је Ђурђевићева Мандалијена штампана у Венецији 1728, а о њеној вредности мисли врло високо („дјело се са сваким њемачким и талијанским дјелом мјерити може” „и што се вели dum et quando dormitat et bonus Homerus, овај Ђорђи никада нит дремље, нит спава, него баш пјева, и то дуго и млого пјева"); за оглед, саопштава Вуку неколико стихова у ћириличкој транскрипцији.

38 То је познато Четворојеванђеље Тројана Гундулића, чије је штампање довршено у Београду 1552. године. 
„Ердељски, који се њемачки зове Weissenburg”, или „Далматински, који је крај мора до Задра”) опрезно се определио за „данашњи српски Београд”, што је било тачно, разуме се, али што он ипак није смео да категорички тврди („ја овако нагађам, а ако се у напредак изнађе и докаже што друкчије, надам се да ће ми се опростити"). Питање о личности издавача тог Јеванђеља још му је било теже, и он то није прећутао: „Ко је бијо овај Тројан Гундулић от великаго града Дубровника? Је ли могуће да је онда у Дубровнику било људи закона нашега (а не може се ни помислити да је Дубровчанин закона римскога својим трошком и трудом штампао црквену књигу за Србе закона грчкога)? По презимену (Гундулић) могло би се помислити да није био отац или дјед Ивана Гундулића, који је послије неко 50 година спјевао Османиду (...) Још је питање овдје треће: да ли је овај Тројан Гундулић сједио онда у Дубровнику или у Биограду, и гдје му је била она кућа, у коју је слова однио и Јеванђелије штампао? Да не буде и он био побјегао из Дубровника па сједио у Биограду?” Безмало све што је Вук смислио као могућу одгонетку тајне о Гундулићу није уопште тачно: Тројан Гундулић није био православни („закона нашега”), већ католик; он није ни отац, ни дед песника Османа; још мање је тачно, најзад, да је бежао из Дубровника, него је тада трговао у Београду, као и многи други његови суграђани; али све се то могло установити так у наше дане, и то не баш једноставним архивским студијама. Но на студије те врсте Вук у оне дане из стотину разлога није могао ни помислити! Исто тако је лако рећи са становишта данашње историјске науке да Караџић није био на добром путу и када је, расправљајући о месту смрти Деспота Стевана (опет у раду Почетак описанија српски намастира) и оспоравајући Рајића, помислио на основу познатог натписа о том догађају „да је о мјесту смрти његове оно истинитије што каже Мавроурбин (у Рајићу књ. III, стр. 128), то јест да је „близу града Сребрнице пао с коња и умро пријеком смрти" и када је ту Орбинову Сребрницу идентификовао с данашњим Рудником.

Суочен, већ од самих почетака свога рада, с низом основних и најкрупнијих питања свога времена, а од њих пре свега: с питањем српскога језика, његовога дефинисања и одређивања његових својстава и његовога пространства; затим: с питањем народа који српским језиком говори и међа̂ до којих он досеже; и коначно: с питањем културе која је на том језику стварана и њене националне припадности, Вук је дошао до својих познатих решења. Та решења он је нашао идући за онда владајућим и пресудним теоријама Ф. Миклошића и делећи до краја исте идеје са J. Копитаром. Њих је затим он у целом даљем свом раду разрађивао, допуњавао, модификовао; њих је образлагао и њих објашња- 
вао; око њих се спорио и за њих водио љуте битке. Та Вукова решења нећемо овде разматрати, јер су она у свим појединостима проучена ${ }^{39}$ и јер стога нема за то потребе. Али, иако су у појединим својим елементима, такође добро познатим, споменута Вукова решења оспорена, иако о неким питањима данас мислимо друкчије но што је о њима Вук мислио - мада и многи спорови непрестано теку, исто тако, - није ипак било могуће, ни овде, мимоићи их муком, поготово што је у њима, тако много, узиман у обзир, спомињан и призиван као сведок стари Дубровник. Вук је то чинио често и радо, а чинили су то, разуме се, исто тако и његови опоненти. Али, како год се о томе сад судило, Вуку увек може служити на част што и када је бивао најсигурнији у својим становиштима, и када их је износио или бранио најодлучније, на свој једноставан, а речит и сликовит начин, није губио смисао за стварност, нити је био спреман да допусти да га схватања одвуку до занемаривања чињеница. Један такав случај из ранога периода његовога рада више је него карактеристичан. Излажући у свом спису Географическо-статистическо описаније Србије (у „Даници” за 1827) како Срба у том часу има, премда су „и ови одовуд, и они одонуд као зид између царства аустријскога и турскога, у свакоме аустријском рату с Турцима највише гинули, и робљени, и свакојако пропадали”, у свему „око пет милиона душа”, од чега три милиона „закона грчкога” (у Србији, Мађарској, Аустријској војничкој граници, Босни, Херцеговини, Црној Гори, Боки Которској и Далмацији) и око два милиона „закона турскога” (у Босни) и „закона римскога” („у Славонији, Рватској, Далмацији и Босни”), он је настављао следећом важном напоменом коју му је диктовала сама ондашња ситуација: „Само прва три милиона зову се Срби или Србљи, а ови други не; него они турскога закона зову се Турци (премда турски говорити не зна ни од 'иљаде један), а од римскога закона зову се или по предјелима, н. п. Славонци, Далматинци, Илирци, Дубровчани, или како ји обично ови други зову Шокци или (у Бачкој) Буњевци”.

Свестан да његова познавања народа, као ни његове прошлости, ни издалека нису потпуна, нити у свему подједнако сигурно заснована, Вук је замишљао и одувек силно желео да крене у велика истраживачка и

39 Литература о томе заиста је огромна и овде ју је немогуће навести ни у избору; довољно је, међутим, за нашу сврху упутити и на поглавље Кюижевни и народни језик у Вука у познатој књизи Александра Белића Вукова борба за народни и книжевни језик (Београд, 1948). 
сакупљачка путовања по оним нашим крајевима у којима није бивао и која није знао. Временом је та његова замисао нарасла до размера, и добила је облике, правог једног подробно разрађеног програма, за чије је остварење он изгледао прилику и тражио помоћи и средстава. Дубровник је у тој замисли од самога почетка био на посебном месту. Још 1824. он је о својој намери да дође у тај град писао младоме Димитрију Милаковићу, али овај га је тада жустро одвраћао: „Видим пак да ви желите овамо доћи, али вам ја искрено кажем да ће вам млого боље бити не ићи, зашто фајде нећете никакве виђети" ${ }^{40}$ Око 1826. чинио је покушаје да за свој велики програм заинтересује руску Императорску Академију. Али је Вук успео да у Дубровник први пут стигне тек 1834, када је на позив Владике Рада ишао у Црну Гору. Град светога Влаха имао му је бити само успутна станица на путу из Трста за Цетиње, а случај се побринуо да му он тада буде много више од тога.

Познато је добро, и овде се на то само подсећа, да је први Вуков боравак у Дубровнику трајао једва тринаест дана, од 31. августа до 11. септембра 1834. Исто се тако знају и многе околности тог његовог боравка: сам их је он саопштавао у писмима која је слао одатле, јављали су их увек будни аустријски обавештајци и дубровачка полиција вишим властима у Задар и налазили су их у службеним актима тражиоци у архивима Дубровника, Задра и Беча. Зна се, тако, да је Вук све то време био „на квартиру” у гостољубивом дому Јеремије Гагића; резиденција рускога конзула била је у онда познатој кући властеле Наталића, касније кући Мисони, „на Плаци пујишкој”, како се некада тај трг звао, а на садашњој Бунићевој пољани, како су стару „пјацу” у наше дане прозвали. ${ }^{41}$ Гагић је Вука „својски дочекао и држао”, али је он, зна се и то одавно, у трагању за певачима народних песама или за саговорницима од којих би бележио „ријечи”, пословице и приповедања, одлазио „готово свако вече у једну крчму иза града" - то је онда чувена Биримишина кафана, која се звала All' Arciduca Federico, а данас је кафана Дубравка, на Пилама - да слуша „ђе се уз гусле пјева”. Познато је најпосле да се Вук у Гагићевом дому уза све није осећао увек слободним (јер би „у кући онакога господина која мора да живи по вољи други’ људи” довођење простих „содата” да певају уз гусле било „велика срамота”), а и да су му неки познаници стављали до знања незадовољство господе дубровачке његовим одласцима у крчме међу „содате” и свакакав свет, на шта је он узвраћао у свом одсечном

40 Вукова преписка, V, 31. Милаковић ово пише „у Рагузи 9. декемвра 1824”.

41 Петар Колендић, Његош у Дубровнику 1833 године, Гласник Скопског научног друштва, XXI, 1940. 
стилу да онде и није дошао да угађа „вољи господе дубровачке, него сам својој" ${ }^{42}$

Понешто о ондашњим Вуковим данима у Дубровнику остало је међутим незнано још увек, а могло би добро доћи да се они сагледају потпуније и боље. Из тих inedita биће најкорисније ослушнути одељке једног Апендинијевог писма Копитару, упућеног у Беч непосредно по Вуковом одласку из Дубровника. Учени Италијан и Вук тада су се први пут срели лично, после дугог литерарног познанства, и изменили су посете узајамно, на обострано задовољство: Апендини сам истиче да му је било драго да упозна „аутора нове српске граматике и речника”. Под непосредним утиском тог сусрета, он бележи затим о Караџићу: „И разговор са њим показује да је дубоко упућен у познавање илирског језика. Велим „илирског језика”, јер кад га он говори искључиво својим српским по читавој Хрватској, као и по приморској и планинској Далмацији, свуда га савршено разумеју и он свакога разуме. Он не тражи језик старих рукописа и књига, већ онај којим се данас говори у народу. Хоће да начини ново издање свога речника. Већ има више од хиљада речи које ваља додати и које се употребљавају, а требаће да одбаци многе друге за које је веровао да живе, али су изван употребе. Исто тако, извршиће измене у својој граматици, бележећи у чему се све прави Далматинци слажу са српским дијалектом, а у чему не. Стефановић је допутовао морем непосредно из Трста у Дубровник, у коме је боравио неколико дана код господина Гагића, правећи своја запажања о дубровачком дијалекту за који налази да је веома добар" ${ }^{43}$

Овај први и тако кратки Вуков боравак у Дубровнику од најдалекосежнијег је значаја за историју нашега језика, али и за историју наше културе уопште. Тих тринаест дана било је Вуку сасвим довољно да о дубровачком говору начини преважна запажања, која ће коначно заокружити систем његове језичке и правописне реформе. Већ 24. септембра 1834. он хита да Копитара упозна са њима, сажимајући их у ону од тада чувену формулу, која као да је и била грађена за вечност: „Данашњи је дубровачки језик прави језик ерцеговачки; ово су највеће између њи' разлике: 1) што се у Дубровнику изговара х (...), 2) што не кажу н. п. ђеца, него дјеи,

42 Вук је свој први боравак у Дубровнику описао и нека запажања о говору и обичајима у њему изнео у писму Ј. Копитару са Цетиња од 12/24. септембра 1834. год. (Вукова преписка, I, 452-454).

43 Апендинијево писмо, упућено из Дубровника 15. септембра 1834, налази ce у препису у рукопису R. 6218/II Националне и свеучилишне библиотеке у Загребу. 
итд. и 3) што имају много и премного ријечи талијански"'.44 Од тада он ће те своје закључке, једва нешто више разрађене, и тек у понечему шире изложене, уносити у свако своје расправљање о језику и понављати у свим својим списима, књигама, језичким документима, полемикама. ${ }^{45}$

Исто ово Вуково путовање у Црну Гору и Боку Которску довело je, потпуно неочекивано, и до другог Вуковог боравка у Дубровнику, сада, само неупоредиво дужег. Пошто се у Котору тешко разболео, „а не имајући онђе никога управо свога", Вук се из тадашње хладне неудобности бокељскога града уклонио у Дубровник, и поново је уточиште, а и пријатељску негу, нашао код Гагића. ${ }^{46}$ Али чим је прездравио, Вук је себи потражио стан негде на Пилама, једно да би могао да живи и ради по властитој вољи и у пуној слободи, друго што му је затвореном у град недостајало ваздуха, а треће и што су му причињавале неугодности степенице господске „палаче” у којој је била Гагићева резиденција. У свему је тада Вук у Дубровнику проборавио око пет месеци (од 18. децембра 1834. до 8. маја наредне године), после чега је опет кренуо за Котор и затим отишао у Црну Гору. ${ }^{47}$ У Дубровнику је Вук пре свега знатно увећао своју лексичку грађу, па ће Српски рјечник, када се 1851. појавио у другом издању, имати чак преко хиљаду речи уз које је стављена назнака „у Дубр.” Када би се само те речи из речника издвојиле, испала би из тога безмало цела књига, која би била као нека енциклопедија о Дубровнику у маломе. Јер у њој места није нашла једино дубровачка лексика, него су ту и назнаке појава из најразноврснијих области живота у Дубровнику, ондашњем и старом, обавештења из његове историје, описи обичаја дубровачког народа, гдекада и веома развијени, примери свакодневних разговора, изреке и пословице. И готово би се рекло да би таква књига могла послужити и као својеврсна слика ондашњих Вукових дубровачких дана: у њој би се видело како он залази у крчме, али како походи и цркве, како обазриво пролази улицама и како посећује пријатељске куће, како обилази рибарницу и пијаце и како је, једном речи, свуда где се окупља

44 У већ наведеном писму Копитару са Цетиња 12/24 септ. 1836 (Вукова преписка, I, 452).

${ }_{45}$ Највише их је унео у познати предговор књиге Српске народне пословище, Беч, 1849.

46 Тако сам Вук јавља Копитару у писму из Дубровника 17/29 јануара 1825 (М. Сарделић, Вук у Дубровнику и у Котору, Срђ, II, 1903, 73-74; Вукова препиcka, I, 625).

${ }^{47}$ Андра Гавриловић, Дубровачка полищија и В. С. Карачић, Полиција, Х, $1923,135$. 
обичан свет, па тамо мотри и пажљиво ослушкује, хвата, записује и памти, пре свега реч, која живот обележава, али из њега и происходи.

Вук је био презадовољан што је тада из Дубровника, као и са целог овог дугог путовања уосталом, донео препуне бележнице сваковрсних најдрагоценијих записа. Његова писма са тих путовања, али и она нешто каснија, када је већ могао да гледа унатраг с више смирености, с поносом говоре о тој богатој жетви. Тако је А. С. Шишкову већ из Дубровника 23. јануара 1835. јављао да му је успело да сабере значајну количину драгоцене грађе за српску граматику и речник. ${ }^{48}$ „А зашто сам тамо ишао? - пита се Вук потом у писму Јосифу Милосављевићу 22. јануара 1836, које је тако лепо да је права штета што га због простра није могућно навести у целини, и наставља одмах с одговором: „Знате да нити сам што куповао, ни продавао, него сам тражио пјесама, пословица, ријечи и остали' такови' беспослица, које су мени и ту свагда биле најмилији посао. Истина сам се доста намучио, и по мору и по суву (...) али шта сам виђео, чуо и накупио, није ми муке жао ни мало". 49 А Кнеза Милоша уверавао је у два маха, новембра 1838. и маја 1839. сводећи рачун о своме раду до тада, да је „које тамо у Србији, које у Црној Гори, у Боки, у Дубровнику, у Хрватској и у Далмацији, скупио много прекрасних народних наших пјесама и осталих драгоцјених ствари, које се тичу литературе, језика, обичаја и познања народа нашега."

Од не мале важности, такође, било је и то што се на овим путовањима знатно ширио и круг Вукових пријатеља и познаника, од којих ће неки остати његови дугогодишњи неоцењиво корисни сарадници. Од тада почиње, на пример, његова веза с дубровачким учитељем и парохом Ђорђем Николајевићем, тада већ прилично познатим „списатељем”, који ће затим трајно задужити нашу књижевност и историју преписом „српских споменика” у дубровачком архиву и издавањем „Српско-далматинског магазина”. Он је Вуку годинама био од неоцењиве помоћи, налазећи у Дубровнику претплатнике за његове књиге, али још више описујући за њега дубровачке обичаје, од којих ће неки ући с нешто Вукових прерада у Караџићеве књиге, а неки ће остати и у његовим хартијама, да буду пу-

48 Вукова преписка, III, 524.

49 У писму од 22. јануара 1836 (Вукова преписка, VI, 704-705); ту је још и Вуково опажање: „Приморска су мјеста врло лијепа виђети, н. п. ђе цијелу зиму у градини цвату руже и на дрвету жуте се наранче, и ђе сад бадеми почињу цватити; али приморски вјетар није за моје од цуга моанато тијело, а још мање приморски путови за моје ноге”.

50 Вукова преписка, II, 684, 685-686. 
бликовани тек у наше дане. ${ }^{51}$ Николајевић је утицао и на друге Вукове дубровачке пријатеље да према својим снагама сарађују такође у Вуковом послу: трговац Јово Лаиновић, тако је управо на његово тражење описао „справу ђевојачку”, један друштвени обичај из времена старе „државе дубровачке", који је опис Вук у пуном његовом пространству унео у Cpnски рјечник из 1852. године..$^{52}$

Најмање среће Вук је у Дубровнику имао у трагању за народним песмама. Веровао је чврсто, у почетку, да их ту мора бити, како оних са самог дубровачког тла, тако и оних из херцеговачког залеђа, одакле људи свакодневно силазе у град. Али његови напори да их се домогне, преко сарадника или лично, давали су само мршаве резултате, или су чак остајали безуспешни. Још око 1824, он је упорно подстицао тада младога Димитрија Милаковића да „купи српске пјесме”, али овај је само обећавао, ${ }^{53}$ а у ствари измицао, страхујући унапред да ће му „труд залуду бити”, „зашто овђе нема ниједнога који би и’ знао, а да који и зна, чини му се срамота таке ствари казивати, чудна је то ствар кад простота мисли да

${ }^{51}$ Веселин Чајкановић, Вукова грађа, СКА, Српски етнографски зборник, књ. I, Четврто одељење, књ. 1, Београд, 1934; V. Gusev, Napomene i dopune uz Vukovu građu objavljenu u redakciji Veselina Čajkanovića, Narodna umjetnost, III, 1964-1965, 144-146; Миленко Филиповић, Сабрана дела Вука Карачића, XVII: Етнограбски списи, Београд, 1972, Поговор, стр. 551. У писму Вуку, од 17/29. октобра 1836. Николајевић се правда што није још послао обећане обичаје дубровачке и кривицу за то баца на Гагића, ,jер ми он њеки пут кад вам баш справљах преводе да пошљем говораше да оно нису национални дубровачки обичаји, и да се сељани, као што и јест, овијех обичаја не држе; но само да су се бивша властела опћине дубровачке по њима владала, да су ово обичаји (разумије се што се укопа тиче) свију европејскијех дворова, сљедоватељно шпецијални, а нису обшти" (Вукова преписка, VII, 461-462). Али већ 9/21 новембра исте године прилаже писму „обичаје дубровачке” (Исто, 463).

${ }_{52}$ Николајевић у нав. писму Вуку 17/29 окт. 1836. вели да је замолио Лаиновића да за Вука опише тај обичај (Исто, 462).

53 У писму из Дубровника од 10. јануара 1835. Милаковић одговара на Вукова подстицања: „На вашу препоруку за скупљање народни’ српски’ (јуначки') пјесама радићу вам барем неколике пјесме скупити; али 'оће се томе времена док удесим ког Ерцеговца који добро зна и који ће ми казати, зашто сваки неће, који зна, да казује, а ја мислим и нису вам још од велике 'итње" (Вукова препиcкa, V, 32). А 5. децембра 1835: „За ерцеговачке пјесме распитујем свакога жива не зна ли когођ), но још никога нисам могао наћи који би и' читаве знао, него само ђекоји знаду комаде од њекије. Ја ћу се и напред старати да и’ изнађем, макар било Бог зна како...” (Исто, 34). 
се је погосподила". ${ }^{4}$ И свој боравак у Дубровнику у пролеће 1835. Вук је користио да песме лично потражи: у априлу је у ту сврху ишао у Цавтат, надајући се да ће их у обиљу наћи код Конављана, ${ }^{55}$ али је донео једва коју. Читаву збирчицу углавном лирских песама даће му доцније један његов пријатељ из редова дубровачких трговаца, Јово Лаиновић, али овај и није био изворни Дубровчанин, и песме је, највероватније, донео у сећању, из Херцегновога, одакле је дошао, или памтећи казивања своје мајке, која је била родом из Фоче. ${ }^{56}$ Стога је Вук закључио, па је тако у предговору новог, бечког издања прве књиге Српских народних пјесама, 1841. године, и назначио, да су, како песме које је он „писао у Дубровнику, но од чељади, која нијесу оданде родом”, тако и ове које је од Лаиновића добио, „готово све праве ериеговачке пјесме, које су гдјешто по приморскоме начину и говору окренуте”, а да „прави Дубровчани - старосједиоци - немају данас никаквијех народнијех пјесама”. Тиме је, међутим, Караџић дирнуо у сам живац праве Дубровчане, поносне на свој град и његову културу, и погођене силно што им се одједном оспорава да имају нешто што је тога часа на највишој цени у свету - народних песама. Нарочито је ојађен овом Вуковом опаском био његов верни читалац, и потоњи пријатељ Медо Пуцић. Још у првој младости он је са заносом читао ране Вукове збирке, и о својим размишљањима над њима, и утисцима о њима, обавештавао пријатеља Балда Бизара. „Ових дана имао сам у рукама - пише он већ 22. децембра 1839, на пример ${ }^{57}$ - извесне волуме збирке илирских „пјесама” и „попијевке”, начињене трудом Вука Стефановића, и мада понеке не превазилазе много поезију Качића Миошића, било би ипак погрешно осудити их све, јер их има много које блистају таквим лепотама да могу да издрже битку с оним што су као најљупкије произвеле стране књижевности”. Своме незадовољству, које га је држало дуго, Медо Пуцић је израза давао још и 1849. године, саопштавајући у „Дубровнику, цвијету народног књиштва", неке народне песме које је сам забележио, и то не ради „историје”, коју оне садрже, већ „за оповрћи ријеч господина

54 Исто, 31 (у писму од 9. децембра 1824).

55 Г. Добрашиновић, Вукова путована, 97.

56 Све то, као и биографске податке о Јову Лаиновићу, изнео је сам Вук у уводу (Мјесто предговора, VI) прве књиге Српских народних пјесама (Беч, 1841). Што је ту речено о Лаиновићу пренето је, међутим, безмало дословно из писма тог сакупљача Вуку из Дубровника „на Петровдан 1840” (Уп. Вукова преписка, VII, 712-713). О Јову Лаиновићу, вид. М. Тврдић (= Андрија Лаиновић), Цртии,а из културне прошлости, Зета, Подгорица, X, 21. V 1939, бр. 20.

57 Писмо је на италијанском језику, а чува се у Хисторијском архиву у Дубровнику (Archiv Bizzarro, RO-158). 
Вука, који се је поспијешио казати да Дубровчани не имаду ниједнијех народнијех пјесама". ${ }^{58}$ Па и када је средином 1854. Медов брат Нико Велики посетио Вука у Бечу, трајале су још увек узајмне срџбе, мада је Вук уверавао Пуцића да много цени песника Меда, „иако ме је он критиковао" и додавао да ће упркос свему они остати добри пријатељи и да ће он сам, у доказ томе, послати коју стварчицу за алманах Дубровник, што није учинио ипак. Вук је осим тога уверавао Ника Великог да је у тврдњи да Дубровчани немају народних песама имао у виду становнике у граду, а не и оне у околини, пошто је и сам забележио многе песме у Конавлима и Ријеци Дубровачкој, које је и публиковао. ${ }^{59}$ Тих година, Вук је, преко свог тадашњег дубровачког кореспондента Ђорђа Николајевића, сазнао, што је младоме Пуцићу остало непознато још увек, да фрањевац Иноченц Чулић, чувени, многозаслужни и - злогласни дубровачки „фратар Глухи”, чува у својим сандуцима, и љубоморно крије од свакога, голему збирку старих „попијевки” и пословица - то је доцније славни рукопис Мале браће, који ће издати тек Валтазар Богишић - али ту збирку он није никако успео да ишчупа од сумњичавог фратра, ${ }^{60}$ што можда и није баш претерано жалио, јер је одувек више волео и ценио, и радије тражио, песме које живе у памћењу народа, но оне које чаме у забораву рукописа. Јамачно је тада више чезнуо да му стигну у руке записи народних песама и пословица из Херцеговине, које је, по Николајевићевој „наруџби”, требало да купи неки „млади калуђер”,61 али ништа није било ни од тог покушаја, ни од те наде.

Вук је и после, у неколико наврата, долазио у Дубровник, али ти потоњи његови боравци увек су од тада бивали кратки и узгредни, и никада више нису имали овако плодне исходе. Средином 1841. он је тек једва једну пуну седмицу провео у граду (од 5. до 12. јуна) када је пратећи „славног руског списатеља” и тајног саветника Николаја Ивановича Надеждина, ишао за Црну Гору, ${ }^{62}$ али тај његов пут, осим чудесних сусрета,

${ }^{58}$ Orsat Počić, Narodne piesme, Dubrovnik cviet narodnog knjižtva, 1849, 231.

59 Писмо Ника Великога Пуцића брату Меду, писано, како по свему изгледа, из Беча пред полазак за Рим, 11. маја 1854. на италијанском језику такође је у Хисторијском архиву у Дубровнику.

${ }_{60}$ Вукова преписка, VII, 469 (у писму од $3 / 15$ августа 1847). Вид. и писма Јеремије Гагића, који је по Вуковом налогу такође покушавао да дође до Чулићевих рукописа, од 1/13 априла 1848 (Вукова преписка, III, 54) и 8/20. маја 1848 (Исто, 55).

${ }^{61}$ Вукова преписка, VII, 470 (у нав. писму Ђ. Николајевића од 3/15. августа 1847).

${ }^{62}$ Г. Добрашиновић, Вукова путоваюа, 101-102. Вук је тада са својим друштвом стигао из Котора у Цавтат, на повратку из Црне Горе, 5. јуна, и одатле одмах 
раздвајања и поновних налажења с Људевитом Гајем и његовом пратњом, који су, можда и не случајном подударношћу, тада такође путовали преко Хрватске и Далмације за Дубровник, ${ }^{63}$ није био обележен никаквим нарочитим значајем. Истина, полицијски извештаји који су ово путовање ревносно пратили спомињали су да је он тада бивао у друштву с појединим ученим Дубровчанима - какав је адвокат и песник Антун Казначић, на пример, - и да се „бавио прикупљањем старих рукописа, истраживањем о броју православнога становништва, о границама области итд.", 64 али у самој ствари Вук није био више од обавештеног сапутника и водича својих руских пријатеља. Доцнији Вукови доласци у Дубровник представљали су још краћа свраћања, на путу за Боку Которску и Црну Гору, или на поврацима отуда. ${ }^{65}$ Такво би остало и његово последње похођење Дубровника, у лето 1863, пред саму смрт такорећи, када је с ћерком Мином бродом ишао из Сплита за Котор, да ту није имао узбудљив сусрет, а испао је то и опроштај, с дугогодишњим пријатељем и сигурно једним од најдрагоценијих сарадника, Вуком Врчевићем, који га је усрдно молио да тај његов пролаз кроз Дубровник и њихово виђење у њему падну „на 25. августа по нашему, кад је свети апостол Вратоломија, моје крсно име, да напијемо у славу божију прије наше смрти". 66

Бесумње је једна од знатних последица Вуковог боравка у Дубровнику и промена одбојног става дубровачких католика према његовим књигама. Док су дотле њихови дубровачки претплатници искључиво православни Срби, „све Бошњаци и Херцеговци”, како је сам Вук говорио, који су у том граду држали трговину, од 1840. године по прилици

продужио за Дубровник. Из Дубровника се 8. јуна писмом јавио својој жени у Беч. Већ 12. јуна сви су наставили пут бродом за Сплит.

${ }^{63}$ Nikola Kojić, Boravak Ljudevita Gaja u Dubrovniku 1841, Dubrovnik, VIII, 1965, 1, стр. 45-56.

64 В. М. Вукмировић, Вук у Дубровнику, 58.

65 Тако је 15. јануара 1861. прошао кроз Дубровник бродом из Котора на путу за Сплит, Задар и Трст (Г. Добрашиновић, Вукова путоваға, 114), али у град, изгледа, није свраћао (В. М. Вукмировић, Вук у Дубровнику, 59).

${ }^{66}$ Вук је с Мином кренуо из Беча јула 1863. и ишао је бродом преко Далмације и Дубровника до Котора (Г. Добрашиновић, Вукова путоваға, 117). Врчевић га је позивао да се састану 25. августа у Дубровнику у писму из Требиња, 8. јула 1863 (Вукова преписка, VI, 653). Да су се они тада доиста у Дубровнику и састали види се из Врчевићевог писма Вуку из Требиња од 10/22. дец. 1863 („после неколико дана нашега растанка у Дубровнику..., Исто, 655). Вук је том приликом Врчевићу дао „три иконе г. Тирола” да их овај некако прода, и оне су се многима свиделе „но до сада не би муштерије ниједној, осим једнога попа те рече да ће купити ону Св. Тројице” (Исто, 656). 
међу „пренумерантима” на Вукове књиге почињу се јављати прави Дубровчани, изданци старих господских кућа, ерудите и песници, или пак учени свештеници, безмало сви из реда такозваних Срба-католика, који у оне деценије играју водећу улогу у дубровачкој интелигенцији. Први је међу њима песник и властелин Медо Пуцић, „граф Орсат Маркович де Поца", како га зове Гагић када 1840. јавља Вуку с радошћу да се овај претплаћује на Српске народне пјесме, ${ }^{67}$ или пак, свијетли господин Орсат Марков Поца”, како га бележи Вук у другој и трећој књизи, 1845. и 1846. ${ }^{68}$ После се дубровачки католици у све већем броју и све чешће јављају у списковима претплатника уз разне Вукове књиге. ${ }^{69}$ Тако се поред „грофа Почића” на Српски рјечник 1852. претплаћује песник и доцнији скупљач народне поезије Петар Франасовић, Корчуланин родом, а тада „парох од Малога Стона” и „љекар” Иво Ав. Казначић, песник и полиграф. За Правительствујушчи совјет српски (1860) Медо Пуцић преузео је чак улогу скупљача претплате у Дубровнику, и обавио ју је заиста успешно, јер су се захваљујући његовој усрдној ревности у претплатнике уписали сви виђенији дубровачки католици, чију дугу листу започиње сам тадашњи бискуп дубровачки Вицко Чубранић, а следе за њим писци, ерудите, свештеници, Петар Франасовић („парох трстенски”), Мато Водопић („парох грушки”), Ловро Кукуљица („професор богословља”), Стијепо Скурла („свештеник”), Перо Будмани, др Иво Казначић и Франо барон Гундулић. На четврту књигу Српских народних пјесама (Беч, 1862) претплатио се опет „његово сијатељство господин кнез Медо Пуцић”, али уз њега и потоњи знаменити лексикограф Перо Будмани. ${ }^{70}$ Очигледно је да је приликом својих боравака у Дубровнику Вук све више ширио

${ }^{67}$ Гагићево писмо је од 8. августа 1840 (Вукова преписка, III, 49).

${ }_{68}$ Српске народне пјесме, књига друга, Беч, 1845, књига трећа, Беч, 1846. Пуцић је у тим књигама једини католик међу претплатницима из Дубровника; остали су прота Ђорђе Николајевић, руски конзул Јеремија Гагић, и десеторица Срба трговаца, на челу са Јовом Лаиновићем.

${ }^{69}$ Ниједан од ових међутим, није се претплатио на Српске народне пословице (Беч, 1849), Ковчежић (Беч, 1849) и Српске народне приповијетке (Беч, 1853).

70 Када Вука више не буде у животу, на његово постхумно издато дело Живот и обичаји народа српскога (Беч, 1867) претплатиће се највећи број угледних католика из Дубровника: кнез Нико Пучић („подпредсједник Саб. Далматинског”), кнез Медо Пучић („народни пјесник и списатељ”), Петар Будмани („списатељ”), Иво др Казначић („списатељ”), Фрањо Гргуревић („професор”), Стјепан Скурла („каноник”), Антун Казали („пјесник”), Ловро Кукуљица („професор богословије”), Петар Франасовић („парох у Трстеному”), Мато Водопић („парох у Лападу”), Иван Стојановић („парох”), Јеро Наталић („чиновник при Окружном суду”), Антун Мартекинић („чиновник при Окружном суду”). 
круг својих пријатеља и поштовалаца у том граду, које је он освајао како неодољивом привлачношћу своје личности, тако и све крупнијим, и сваким даном очитијим значајем свога рада и својих књига. Није зато чудо што му привржени Гагић већ после првог његовог одласка из Дубровника шаље поздраве многих Дубровчана из редова тамошњег православног трговачког света - Лучића, Томића, Шкуљевића - али и што одмах уз то додаје: „И многи Латини Дубровчани питају за вас и поздрављају вас”."1

Од најранијих Вукових боравака у Дубровнику, у којима је огромно много сазнао, чуо и видео, па све до његових последњих дана, у свим његовим списима срећу се помени Дубровника и осврти на његов језик и његову културу. Непрестанце рекло би се Вук осећа потребу да се у својим размишљањима, као и у својим доказивањима, позива на појаве, или да указује на примере из тог језика и из те културе. То он чини кад пише о гласу $ъ$ и о његовом значају у словенским „нарјечијима”, којима међе види „од Дубровника до Камчатке”72 или када расправља о рефлексима истога гласа у „јужном нарјечију”, и кад истиче да се $\partial$ и $и$ испред Ђ, за разлику од говора у Херцеговини, Црној Гори и Боки, где постају ち и $\hbar$, „по њекојим мјестима, особито к западу (као у Дубровнику и у Босни - особито по варошима)" не претварају, већ остају дj и $m j$, то је, по њему, „варошки или господски говор јужнога нарјечија, који ми велимо да би требало узети за књижевни језик у свему народу нашему".73 Појаве и особености дубровачког говора Вук спомиње и цитира и иначе безмало сваки час у својим расправљањима о језику; по његовом суду, „у Дубровнику се говори чисто српски"74 и тај говор стога за њега обично има пресудну снагу ауторитета и норме. Тако се, разматрајући изговор краткога $b$ после $р$ опредељивао за $e$, иако је већ у његовом рођеноме говору било друкчије: „Истина да сам ја у Тршићу још у дјетињству слушао рјечит, грјешник, грјешнииа, али у Дубровнику и у Црној Гори говори

71 У писму од 14. новембра 1843 (Вукова преписка, III, 37).

72 У напоменама уз Писмо П.(авла) Б.(ерића) Jосифу Миловуку о Матици српској у „Даници” за 1834. год.

73 У Одговору на ситниие језикословне Г. Ј. Хацића - М. Светића (Беч, 1839), као и у спису Главна правила за јужно нарјечје („Шумадинка”, 1850).

74 Ђорђе С. Ђорђевић, Један Вуков рад, Коло, I, 1889, 512-513: реч је о Вуковој оцени дела Die Sprachenhalle од Auera, штампаној у извештају бечке царске академије наука, 1848. 
се грешник, грешница..."75 У свом преводу Новога завјета (1847) одлучио се Вук за реч тја („мјесто славенскога даже и турскога чак”), јер се тако „говори у Дубровнику”, мада се „и у Боци и у Црној гори каже ћа”. Дубровник и одлике његовога говора срећу се често и у Вуковим полемикама, када, на пример, води спорове о „гдјекојим ријечима”, када се залаже да се у наш језик узме, поред речи кнез уместо књаз, и реч вијеће уместо coвjem, јер је та друга реч (вијеће) „позната у народу с тијем истијем значењем које се ријечи совјет даје, и не само што се тако узимала у Дубровачкој републици, него и у Русији..., ${ }^{76}$ или када напомиње да „народ наш по многијем мјестима" изоставља у говору завршно $m$ после сугласника $c$ или $и$ (милос м. милост, плаш м. плашт) и да су „Дубровчани тако и писали" ${ }^{77}$ Гдекад је, међутим, Вук говорећи о дубровачким стварима имао и по коју реч неслагања и критике: о правопису старих Дубровчана није мислио најбоље, ${ }^{78}$ а тражећи одговор на питање о толиким сувишним слоговима у осмерцима Гундулићевог Османа - сувишни су се они чинили њему, као и Бабукићу и Вразу, иако је по среди била једна од специфичности ондашње версификације, - он је, боље и истини ближе од свих других у оно време, помишљао да „може бити да су Дубровчани овако што видјели у талијанскоме језику, па у своме још и претјерали."79 Али и када је у поетском језику Дубровчана налазио артифицијелности и подвлачио насилне творевине ради стиха и слика, није престајао да истиче „да су књиге дубровачкијех пјесника за језик свију нас скровиште (тј. благо) које се не може процијенити" ${ }^{80} \mathrm{Oн} \mathrm{је} \mathrm{као} \mathrm{ослонац} \mathrm{својој} \mathrm{борби}$ за народни језик спомињао да су „браћа наша закона римскога, особито Дубровчани и Далматинци” писали већ у XVI веку народним језиком „у највећи јек”, 81 док се „у нас почело писати народнијем језиком од Доситија Обрадовића”, као што је, исто тако, „сила пута мислио и говорио да

75 Нав. Вуков рад Главна правила за јужно нарјечје.

76 Вуков одговор на лаж и опадана у Српскоме улаку (Беч, 1844).

77 Одговор Г. Евг. Јовановичу на „примјечанија на книгу Писма Вука Ст. Каращића и Саве Текелије”, Србски народни лист, 1846, бр. 19. и 20.

78 У Посланици Анту Кузманићу у Задар (Slavische Bibliothek, I, 1851, 90-96) истицао је да су стари Дубровчани писали „чистијем јужнијем нарјечјем народа нашега (као и ја ово што пишем)”, али је додавао да „они нијесу имали савршена правописа по коме би се могло свуда онако читати као што је говорио онај који је писао".

${ }^{79}$ Odgovor (Vjekoslavu Babukiću) g. Vuka Stef. Karadžića, Kolo, Zagreb, IV, 1847.

80 Иcmo.

81 (Одговор на) „Утук III језикословни” од М. Светића, Сербски народни лист, ХII, 1847. 
би било вриједно нашијем словима наштампати сва дјела дубровачкијех и гдјекојијех далматинскијех пјесника без икакве промјене у језику", ${ }^{2}$ јер су „старија дјела браће наше закона римскога за наше данашње списатеље веће скровиште и чистији извор од нашијех данашњијех црквенијех књига". Није притом Вук био ни за какву једностраност и једносмерна утицања. „Ја мислим на против да и браћа наша закона римскога ваља да читају наше, и старе и данашње, црквене књиге, али и ми, особито списатељи и књижевници, да читамо књиге њихове, особито старијих пјесника". ${ }^{83}$ Колики је ауторитет, и какво место у његовој свести о језику, имала стара дубровачка литература, и до које је мере он веровао да може ићи дејство њенога примера, најбоље се види по томе што је залажући се за јужно (херцеговачко) наречје као „најприличније да га у писању сви примимо”, један од веома важних аргумената за њега био то што је „оно нарјечије и дубровачкијех списатеља” и што се „тако само чрез њега можемо ујединити с нашом браћом римскога закона која с радошћу нама руке пружају". ${ }^{44}$

Све што се од нашега предмета овде могло дотаћи даје довољно основа, сасвим извесно, да без дугих и великих закључивања сме рећи да би без Дубровника, његовога говора и његове културе и Вук и његово дело, а тиме и „српско књижество”, разуме се, били неизбежно друкчији, а сигурно и сиромашнији. Али је исто тако извесно да је и вековној слави Дубровника са своје стране и Вук допринео не мало, и да без њега та слава такође не би била потпуна. А у тој чињеници је врло много лепоте по себи, и много части за обе стране у односу који нас је овога пута занимао.

${ }^{82}$ Исто.

${ }^{83}$ Исто.

${ }^{84}$ Вука Стеф. Караџића и Саве Текелије писма високопреосвештеноме господину Платону Атанацковићу православноме владиии будимскоме о српскоме правопису са особитијем додацима о српском језику, у Бечу, 1845. 